\title{
Replication Kinetics of Rickettsia raoultii in Tick Cell Lines
}

\author{
Nurul Aini Husin ${ }^{1,2,+}$, Jing Jing Khoo ${ }^{1,+}{ }^{,}$Mulya Mustika Sari Zulkifli ${ }^{1}$, Lesley Bell-Sakyi ${ }^{3}$ (i) \\ and Sazaly AbuBakar $1,4, *$ (I)
}

1 Tropical Infectious Diseases Research and Education Centre, Level 2, High Impact Research Building, Universiti Malaya, Kuala Lumpur 50603, Malaysia; nurulainihusin@yahoo.com (N.A.H.);

khoojj@gmail.com (J.J.K.); mulyamustika@um.edu.my (M.M.S.Z.)

2 Institute for Advanced Studies, Universiti Malaya, Kuala Lumpur 50603, Malaysia

3 Department of Infection Biology and Microbiomes, Institute of Infection, Veterinary and Ecological Sciences, University of Liverpool, Liverpool L3 5RF, UK; L.Bell-Sakyi@liverpool.ac.uk

4 Department of Medical Microbiology, Faculty of Medicine, Universiti Malaya, Kuala Lumpur 50603, Malaysia

* Correspondence: sazaly@um.edu.my

+ These authors contributed equally to the work.

check for updates

Citation: Husin, N.A.; Khoo, J.J.; Zulkifli, M.M.S.; Bell-Sakyi, L.; AbuBakar, S. Replication Kinetics of Rickettsia raoultii in Tick Cell Lines. Microorganisms 2021, 9, 1370. https://doi.org/10.3390/ microorganisms 9071370

Academic Editor: Vijay Pancholi

Received: 24 May 2021

Accepted: 20 June 2021

Published: 24 June 2021

Publisher's Note: MDPI stays neutral with regard to jurisdictional claims in published maps and institutional affiliations.

Copyright: (C) 2021 by the authors. Licensee MDPI, Basel, Switzerland. This article is an open access article distributed under the terms and conditions of the Creative Commons Attribution (CC BY) license (https:/ / creativecommons.org/licenses/by/ $4.0 /)$.
Abstract: Rickettsia raoultii is one of the causative agents of tick-borne lymphadenopathy in humans. This bacterium was previously isolated and propagated in tick cell lines; however, the growth characteristics have not been investigated. Here, we present the replication kinetics of $R$. raoultii in cell lines derived from different tick genera (BME/CTVM23, RSE/PILS35, and IDE8). Tick cell cultures were infected in duplicate with cryopreserved $R$. raoultii prepared from homologous cell lines. By 12-14 days post infection, 100\% of the cells were infected, as visualized in Giemsa-stained cytocentrifuge smears. R. raoultii growth curves, determined by rickettsiae-specific gltA qPCR, exhibited lag, exponential, stationary and death phases. Exponential phases of 4-12 days and generation times of 0.9-2.6 days were observed. R. raoultii in BME/CTVM23 and RSE/PILS35 cultures showed, respectively, 39.5- and 37.1-fold increases compared to the inoculum. In contrast, multiplication of $R$. raoultii in the IDE8 cultures was 110.1-fold greater than the inoculum with a 7 -day stationary phase. These findings suggest variation in the growth kinetics of $R$. raoultii in the different tick cell lines tested, amongst which IDE8 cells could tolerate the highest levels of $R$. raoultii replication. Further studies of $R$. raoultii are needed for a better understanding of its persistence within tick populations.

Keywords: vector-borne disease; Rickettsia raoultii; infectious disease; tick cell line

\section{Introduction}

Rickettsia raoultii is a spotted fever group rickettsial species, which was first described in Dermacentor nuttalli (reported then as genotypes DnS14 and DnS28) and Rhipicephalus pumilio (genotype RpA4) ticks from Siberia [1]. It was later described from Dermacentor spp. ticks, mainly D. nuttalli, Dermacentor reticulatus, Dermacentor marginatus and Dermacentor silvarum, from Russia [2], countries in Europe [2-5], and Asia [6-9]. R. raoultii has also been reported in Haemaphysalis erinacei [10] and Ixodes ricinus [11] ticks, and even in other arthropod species, such as Melophagus ovinus [12], suggesting a possible wider host range in addition to Dermacentor spp. ticks. Rickettsia spp., genetically related to R. raoultii (>98\% identity in target genes), were also described from Dermacentor spp. ticks from Southeast Asian countries $[13,14]$.

R. raoultii, together with Rickettsia slovaca, is a causative agent of tick-borne lymphadenopathy (TIBOLA), also known as Dermacentor-borne necrosis erythema and lymphadenopathy (DEBONEL) [15]. The syndrome is associated with a tick bite, an eschar at the tick bite site (frequently on the scalp) and cervical lymphadenopathies [15]. R. raoultii infections with erythematous rash and fever, but without lymphadenopathy, were also reported in patients from China [16]. Other reported clinical manifestations of $R$. raoultii 
infections include meningeal syndrome [17], and neurological abnormalities such as eyelid droop and high cerebrospinal pressure [18]. Although normally associated with mild infections, more severe infections with leukopenia, thrombocytopenia and septic parameters have also been reported, suggesting varying degrees of virulence for [19], or susceptibility to $R$. raoultii. Although TIBOLA/DEBONEL is attributed to both $R$. slovaca and R. raoultii, studies have suggested that $R$. raoultii is more highly prevalent among Dermacentor spp. ticks [15]. However, there have been more reports of $R$. slovaca infection, implying that $R$. raoultii is less pathogenic [15] or less frequently transmitted to humans. Despite its widespread presence in Europe, Russia, and Asia, information relating to the virulence and pathogenicity of $R$. raoultii is still scarce; more thorough characterization is necessary to understand these aspects of the bacterium.

R. raoultii was first isolated from Dermacentor spp. ticks into L929 and Vero cells by Mediannikov and co-workers [2]. Later, $R$. raoultii was also isolated into embryo-derived tick cell lines originated from Rhipicephalus microplus [20-23] and Rhipicephalus sanguineus [24]. The bacterium was also found to be able to infect cell lines derived from Dermacentor albipictus and Dermacentor nitens [20]. Since ticks are natural reservoirs and vectors of some Rickettsia spp., tick cell lines are a useful system for the isolation and propagation of $R$. raoultii from ticks or clinical samples for further investigation of its virulence and pathogenicity [20,24].

The purpose of this study was to establish the infection rates and replication kinetics of $R$. raoultii in three tick cell lines-BME/CTVM23 derived from R. microplus [20], RSE/PILS35 derived from R. sanguineus [25], and IDE8 derived from Ixodes scapularis [26]. The aim was to increase understanding of the growth characteristics of $R$. raoultii in tick cell lines and provide the basis for further studies into its invasiveness for host cells.

\section{Materials and Methods}

\subsection{Maintenance of Tick Cell and R. raoultii Cultures}

The tick cell lines and bacterial culture were obtained from the Tick Cell Biobank, University of Liverpool, UK and maintained in the Tick Cell Biobank Asia Outpost at TIDREC, Universiti Malaya, Malaysia. The R. microplus-derived cell line BME/CTVM23 at passage 77 [20] and $R$. sanguineus-derived cell line RSE/PILS35 at passage 16 [25] were grown at $32{ }^{\circ} \mathrm{C}$ and $28{ }^{\circ} \mathrm{C}$, respectively, in L-15 (Leibovitz) medium supplemented with $10 \%$ tryptose phosphate broth (TPB), $20 \%$ fetal bovine serum (FBS), 2 mM L-glutamine and antibiotics (100 units $/ \mathrm{mL}$ penicillin and $100 \mu \mathrm{g} / \mathrm{mL}$ streptomycin). The I. scapularisderived cell line IDE8 at passage 98 [26] was maintained at $32{ }^{\circ} \mathrm{C}$ in L-15B medium [27] supplemented with $10 \%$ TPB, $5 \%$ FBS, $0.1 \%$ bovine lipoprotein (MP Biomedicals, Solon, $\mathrm{OH}$, USA), $2 \mathrm{mM}$ L-glutamine and antibiotics. All cell lines were maintained in sealed flat-sided culture tubes (Nunc, Thermo Fisher, Loughborough, UK) with $\frac{3}{4}$ of the medium replaced weekly and sub-culture performed at 1-3-month intervals.

$R$. raoultii (strain Białystok1) was provided in a culture maintained in the BME/CTVM23 cell line [21]. The bacterial culture was maintained following the conditions for BME/ CTVM23 cells outlined above, but with incubation temperature at $28{ }^{\circ} \mathrm{C}$ instead of $32{ }^{\circ} \mathrm{C}$. The R. raoultii was maintained by passaging the bacteria onto fresh BME/CTVM 23 cells once every three weeks.

\subsection{Preparation of $R$. raoultii Stock Culture}

Heavily infected BME/CTVM23 cells were resuspended by pipetting and forcibly passed through a $25 \mathrm{G}$ needle 5 times to release the bacteria from the cells. The resulting suspension was filtered through a $2.0 \mu \mathrm{m}$ membrane filter and centrifuged at $1000 \times g$ for $5 \mathrm{~min}$ at $4{ }^{\circ} \mathrm{C}$, to remove intact cells and cell debris. Next, equal volumes of the suspension were used to inoculate IDE8 and RSE/PILS35 cell cultures. The inoculated cells were maintained at $28{ }^{\circ} \mathrm{C}$ and were observed daily for signs of cytopathic effects using a BMI-100 inverted microscope (Biobase, Shandong, China). Once severe cytopathic effects were observed (i.e., most cells rounded up or detached from the bottom of the culture 
tube, indicating heavy $R$. raoultii infection), aliquots of the infected cells were immediately cryopreserved in their respective culture medium with the addition of $10 \%$ dimethyl sulfoxide as described previously [21], to be used as the bacterial stock for infection studies. An aliquot of each of the infected cells was used for DNA extraction and PCR amplification of the tick-specific partial 16S rRNA sequence utilizing the primer pair $16 \mathrm{~S}+1$ and $16 \mathrm{~S}-1$ from a previously published protocol [28]. To exclude the possibility that any carry-over of live BME/CTVM23 cells into the recipient IDE8 and RSE/PILS35 cultures had occurred, the PCR amplicons were sequenced and subjected to NCBI BLAST analysis at 7 and 13 days post inoculation (dpi).

\subsection{Infection of Cells}

One day prior to infection, duplicate cultures were set up in $2.2 \mathrm{~mL}$ culture medium with the following cell densities for each cell line to be tested: the BME/CTVM23 cells were seeded at $6 \times 10^{6}$ cells $/ \mathrm{mL}$, RSE/PILS35 cells were seeded at $2 \times 10^{6}$ cells $/ \mathrm{mL}$ and IDE8 cells were seeded at $5 \times 10^{6}$ cells $/ \mathrm{mL}$. To each culture, $200 \mu \mathrm{L}$ of thawed, cryopreserved bacterial stock prepared from the homologous cell line was added. Post infection, the cell cultures were monitored daily for signs of cytopathic effects. Cells were collected at the indicated intervals for preparation of Giemsa-stained cytocentrifuge smears and for bacterial quantification by quantitative PCR (qPCR) as described below. Fresh medium was used to replace the volume that was removed when the cell suspension was taken from the culture tube.

\subsection{Visualization of Bacteria by Giemsa Staining}

Cytocentrifuge smears were prepared from $50 \mu \mathrm{L}$ of cell suspension centrifuged for $5 \mathrm{~min}$ at $1000 \mathrm{rpm}$. in a Cytospin 3 cytocentrifuge (Shandon, Pittsburgh, PA, USA). The resultant smears were air-dried, fixed in methanol for $3 \mathrm{~min}$, stained with Giemsa (Merck, Darmstadt, Germany) and rinsed 3 times with water buffered to $\mathrm{pH} 7$. The Giemsa-stained smears were examined under a compound microscope (GX Microscopes, Suffolk, UK) at $1000 \times$ magnification for the presence of bacteria. The GXCAM digital camera and GXCapture software were used to capture images of the cells. The percentage of infected cells was determined by calculating the number of infected cells $\times 100$, divided by the total number of cells (at least 200 cells examined for each sample).

\subsection{Quantification of Bacteria by $q P C R$}

DNA was extracted from $200 \mu \mathrm{L}$ of cell suspension collected from each time point of the experiment using a NucleoSpin ${ }^{\circledR}$ tissue kit (Macherey-Nagel, Düren, Germany) following the manufacturer's protocol. DNA was also extracted from a $200 \mu \mathrm{L}$ aliquot of cryopreserved bacterial stock prepared from the homologous cell line as the representation of the number of bacterial DNA copies present at time point $0 \mathrm{dpi}$ in the infection time course. A previously published qPCR protocol targeting a 74 base-pair fragment of the Rickettsia citrate synthase $(\mathrm{glt} A)$ gene [29] was used to quantify absolute numbers of $R$. raoultii in the infected cultures. The qPCR was performed using a CFX96 touch real-time PCR detection system (Bio-Rad, Watford, UK) with a 6-carboxyfluorescein (FAM) and black-hole quencher (BHQ1-) labelled TaqMan probe (Integrated DNA Technologies, Singapore). All reactions were prepared in $25 \mu \mathrm{L}$ reaction volumes, comprising final concentrations of $1 \times$ TaqMan fast advanced master mix (Applied Biosystems, Waltham, MA, USA), $200 \mathrm{nM}$ of each primer and probe, and $1 \mu \mathrm{L}$ DNA template. The PCR cycling conditions were as follows: initial holding temperature at $50{ }^{\circ} \mathrm{C}$ for $3 \mathrm{~min}$, followed by $95^{\circ} \mathrm{C}$ for $5 \mathrm{~min}$ and 40 cycles of $95^{\circ} \mathrm{C}$ for $20 \mathrm{~s}$ and $60^{\circ} \mathrm{C}$ for $40 \mathrm{~s}$. To determine the bacterial DNA copy number, a pIDTSmart (Amp) vector (Integrated DNA Technologies, The Gemini Singapore science Park 1l, Singapore) containing the gene target was used to construct a standard curve with serial dilution in the range of $1 \times 10^{5}$ to $1 \times 10^{13}$ copies.

To determine the numbers of tick cells in the cultures, a qPCR assay targeting a 77 basepair fragment of a tick single-copy nuclear gene, ribosomal protein L6 (rpl6) was performed 
as described previously [30]. Each reaction contained final concentrations of $1 \times$ SensiFast SYBR no-ROX master mix (Bioline, UK), $200 \mathrm{nM}$ each of forward and reverse primers and $1 \mu \mathrm{L}$ DNA at a final volume of $20 \mu \mathrm{L}$. The reactions were conducted with an initial denaturation at $95^{\circ} \mathrm{C}$ for $10 \mathrm{~min}$, followed by 35 cycles of denaturation at $95^{\circ} \mathrm{C}$ for $15 \mathrm{~s}$, annealing at $55^{\circ} \mathrm{C}$ for $30 \mathrm{~s}$ and extension at $72{ }^{\circ} \mathrm{C}$ for $15 \mathrm{~s}$. Following amplification, a melt curve from $55^{\circ} \mathrm{C}$ to $95{ }^{\circ} \mathrm{C}$ with increasing increments of $0.5^{\circ} \mathrm{C}$ per cycle was examined to confirm that only a single target had been amplified. To determine the tick DNA copies, a synthesized gene target obtained from the Tick Cell Biobank was used to construct a standard curve with serial dilutions in the range of $5 \times 10^{-1}$ to $5 \times 10^{6}$ copies. The generation times for $R$. raoultii in each tick cell culture were calculated using the following equation [31]:

$$
\text { Mean generation time }=0.301 t /\left(\log _{10} N_{t}-\log _{10} N_{0}\right)
$$

where $N_{0}$ is the number of bacteria at the beginning of the exponential phase, $N_{t}$ is the number of bacteria at the end of the exponential phase and $t$ is the interval between $N_{0}$ and $N_{t}$.

\section{Results}

\subsection{Sequencing of the Tick-Specific Partial 16S rRNA Gene}

Sequencing of the PCR amplicon from the inoculated IDE8 and RSE/PILS35 cells confirmed the absence of the $R$. microplus $16 \mathrm{~S}$ rRNA sequence in either of the recipient cultures at 7 and 13 dpi. Therefore, this indicates that there was no carry-over of live BME/CTVM23 cells into the recipient cultures of the IDE8 and RSE/PILS35 cells.

\subsection{Microscopic Observation of $R$. raoultii-Infected Tick Cells}

Duplicate cultures of each of BME/CTVM23, RSE/PILS35 and IDE8 cell lines were infected with $R$. raoultii and monitored at the selected time points by Giemsa-stained cytocentrifuge smears for the presence of bacteria. Noticeable cytopathic effects in the infected BME/CTVM23, RSE/PILS35 and IDE8 cell lines were observed, starting from 8, 6 and 7 dpi, respectively. The diameters of the uninfected BME/CTVM23 and IDE8 cells in the Giemsa-stained cytocentrifuge smears ranged from 10 to $20 \mu \mathrm{m}$ (Figure 1A,B), while the uninfected RSE/PILS35 cells ranged from 10 to $50 \mu \mathrm{m}$ (Figure 1C). Pleiomorphic rickettsiae-like bacteria were observed in the cytoplasm of the tick cells, after infection with $R$. raoultii (Figure 1D-F). There was no observable difference in the size of the cells after infection with $R$. raoultii. Rickettsiae-like bacteria were observed in all the infected cultures, starting from 3 dpi. However, at this point, not many cells were infected in the BME/CTVM23 cultures and most of the bacteria were still extracellular. All the cells in both the BME/CTVM23 cultures appeared to be infected at $15 \mathrm{dpi}$. Large numbers of bacteria were seen outside the cells, together with many lysed cells in the cytocentrifuge smears by 18 dpi. For the RSE/PILS35 and IDE8 cultures, the rickettsiae-like bacteria were readily observed inside the cell cytoplasm at $3 \mathrm{dpi}$. More cells with bacteria inside the cell cytoplasm were seen at $7 \mathrm{dpi}$. Many infected cells were lysed and large numbers of bacteria were seen outside the cells after $10 \mathrm{dpi}$. By 15,13, and $14 \mathrm{dpi}$, the culture medium in infected BME/CTVM23, RSE/PILS35 and IDE8 cultures, respectively, started to turn pink, suggesting that cells had begun to die.

\subsection{Bacterial Infection Rates in Tick Cell Cultures}

The percentages of infected cells in the two BME/CTVM23 cell cultures increased steadily from 0 to $12 \mathrm{dpi}$ (Figure 2A). At days 5 and $10 \mathrm{dpi}$, the mean infection rates were $61.0 \%$ and $90.0 \%$, respectively, and by $12 \mathrm{dpi}, 100 \%$ of the cells from both the cultures were infected. Similarly, the numbers of infected cells in both the RSE/PILS35 cell cultures increased steadily from 0 to $10 \mathrm{dpi}$ (Figure 2B), with mean infection rates at 3, 10 and $14 \mathrm{dpi}$ of $28.5 \%, 97.0 \%$ and $100 \%$, respectively. A lag phase was observed between 0 to 3 dpi in both the $R$. raoultii-infected IDE8 cultures (Figure 2C). This was followed by a steady 
increase in the percentage of infected cells to $10 \mathrm{dpi}$, when the mean infection rate reached $94.5 \%$. Subsequently, $100 \%$ of the cells in both the cultures were observed to be infected at 14 dpi.

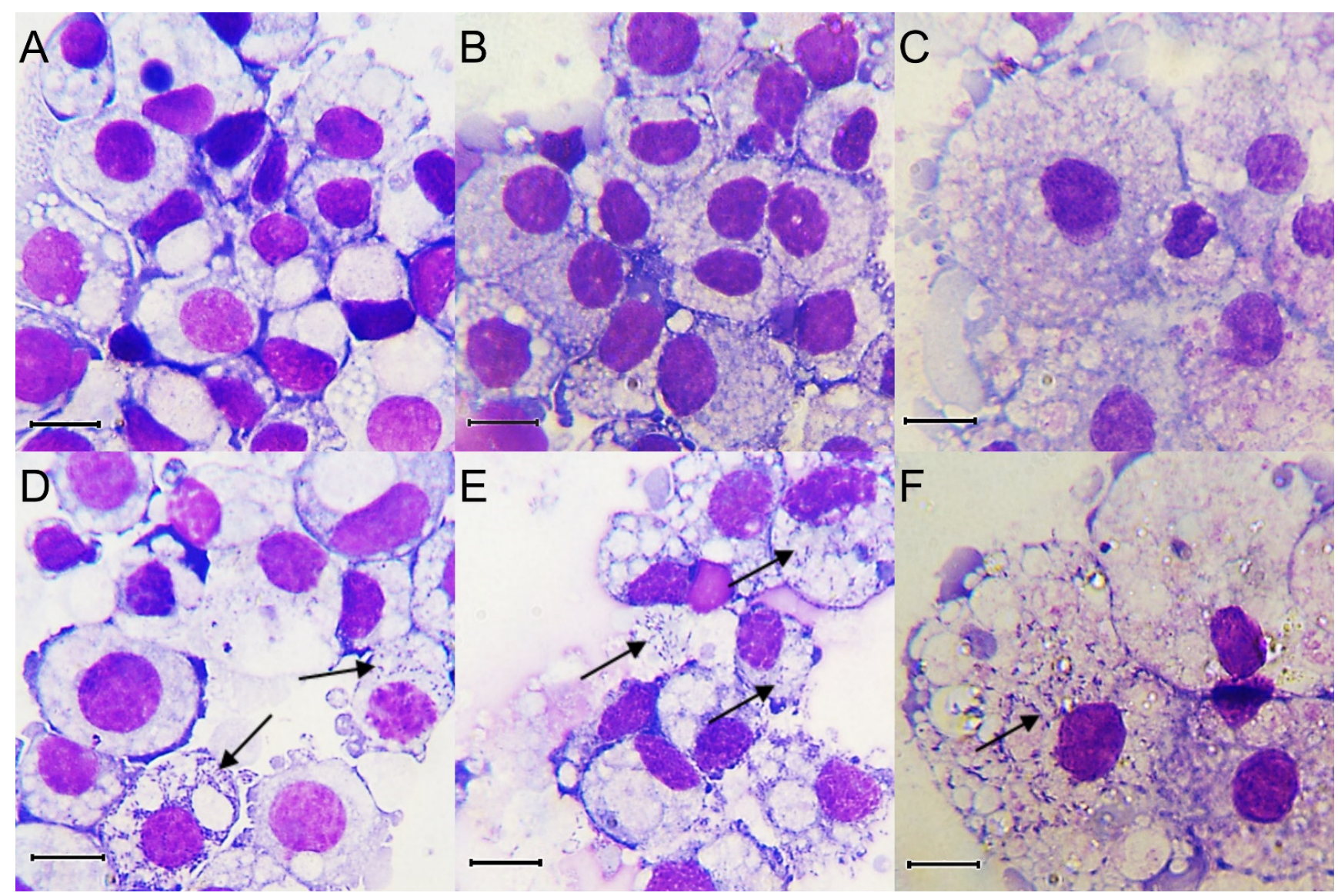

Figure 1. Giemsa-stained cytocentrifuge smears prepared pre-infection (A-C) and at 7 days post infection (D-F) with Rickettsia raoultii of tick cell lines BME/CTVM23 (A,D), IDE8 (B,E) and RSE/PILS35 (C,F). Arrows indicate the presence of bacteria. Scale bars represent $10 \mu \mathrm{m}$.

\subsection{Replication Kinetics of $R$. raoultii in Tick Cell Cultures}

The numbers of $R$. raoultii were represented by the copy numbers of the rickettsiaespecific gltA gene target determined by qPCR. For the BME/CTVM23 cultures, approximately $2.63 \times 10^{9}$ DNA copies of $R$. raoultii were used to initiate infections in both cultures, as indicated on 0 dpi. (Figure 3A). The curves for both the BME/CTVM23 cell cultures demonstrate an exponential increase from 0 to $15 \mathrm{dpi}$, and a subsequent declining phase from 15 to 18 dpi. The mean generation time for $R$. raoultii in the BME/CTVM23 cultures was 2.2 days. On $15 \mathrm{dpi}$, the highest mean copy number was recorded at $1.04 \times 10^{11}$ copies $/ \mathrm{mL}$, representing an approximately 39.5 -fold increase compared to the inoculum. Concurrently, a gradual decrease in the tick cell numbers, as represented by the rpl6 target copy number, was observed in both the $R$. raoultii-infected BME/CTVM23 cell cultures from 3 to $15 \mathrm{dpi}$, followed by a steeper decline as the infected cells began to die (Figure 3B).

Approximately $6.85 \times 10^{7} \mathrm{DNA}$ copies $/ \mathrm{mL}$ of $R$. raoultii were used to initiate infections in both the RSE/PILS35 cell cultures, as indicated at 0 dpi (Figure 3C). The curve for both the RSE/PILS35 cell cultures demonstrated an initial lag phase from 0 to $3 \mathrm{dpi}$. This was followed by an increase in the glt $A$ target copies, from $3 \mathrm{dpi}$ to $14 \mathrm{dpi}$, and a subsequent decrease, from $14 \mathrm{dpi}$ to $17 \mathrm{dpi}$, in culture 1 . On the other hand, in culture 2 , the exponential increase in the glt $A$ target copies, from 3 to $10 \mathrm{dpi}$, was followed by a stationary phase 
between 10 and $14 \mathrm{dpi}$, and a subsequent decrease from $14 \mathrm{dpi}$ to $17 \mathrm{dpi}$. The $R$. raoultii generation times were calculated to be 2.6 and 1.6 days in cultures 1 and 2, respectively. On $14 \mathrm{dpi}$, the highest mean copy number was recorded at $2.54 \times 10^{9}$ copies $/ \mathrm{mL}$, representing an approximately 37.1-fold increase compared to the inoculum. In parallel, the tick cell numbers remained fairly stable from 3 to $7 \mathrm{dpi}$ in both the R. raoultii-infected RSE/PILS35 cell cultures, and were followed by a subsequent decline until 21 dpi (Figure 3D). However, in RSE/PILS35 culture 1, an increase in the copy number of the rpl6 gene was observed at $14 \mathrm{dpi}$.
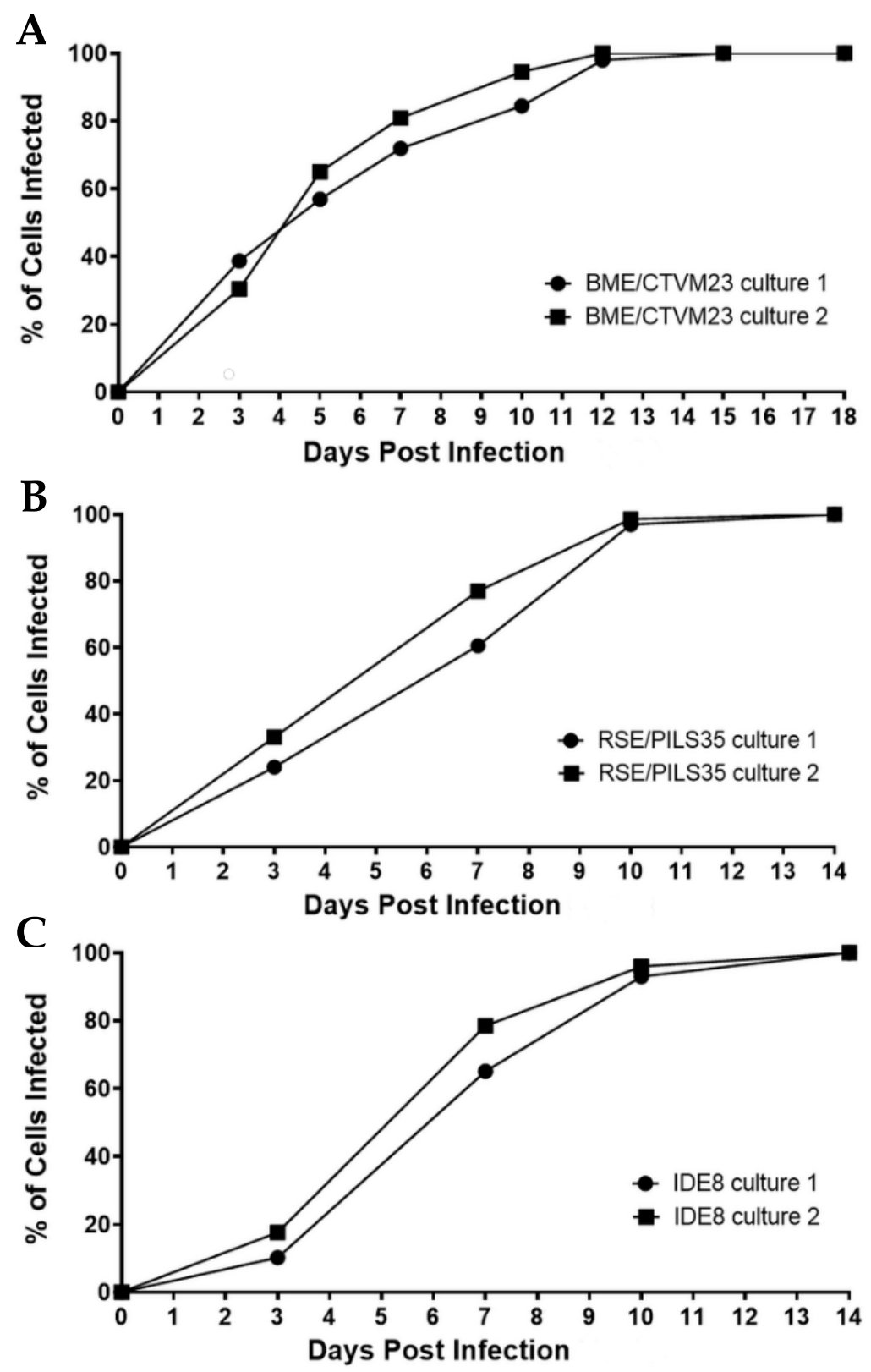

Figure 2. Rickettsia raoultii infection rate curves in two replicate cultures in each of the tick cell lines BME/CTVM23, RSE/PILS35 and IDE8. (A): R. raoultii-infected BME/CTVM23 cultures, (B): $R$. raoultii-infected RSE/PILS35 cultures, (C): $R$. raoultii-infected IDE8 cultures. The infection rates were calculated based on the percentage of infected cells observed among 200-300 cells counted in Giemsa-stained cytocentrifuge smears prepared at the indicated days post infection. 
A

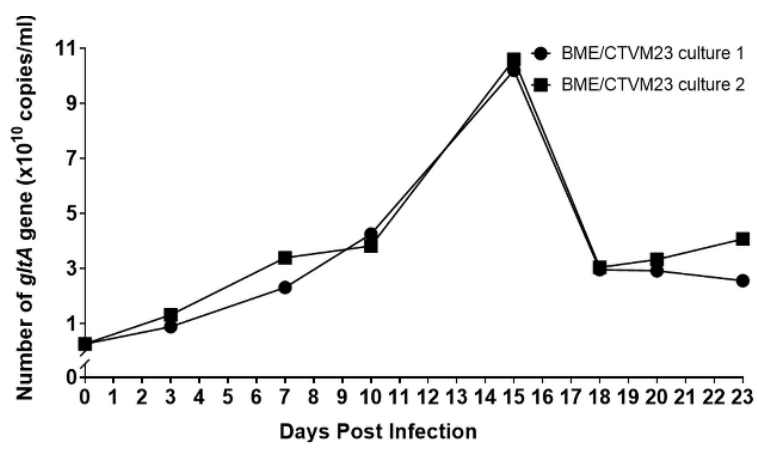

C
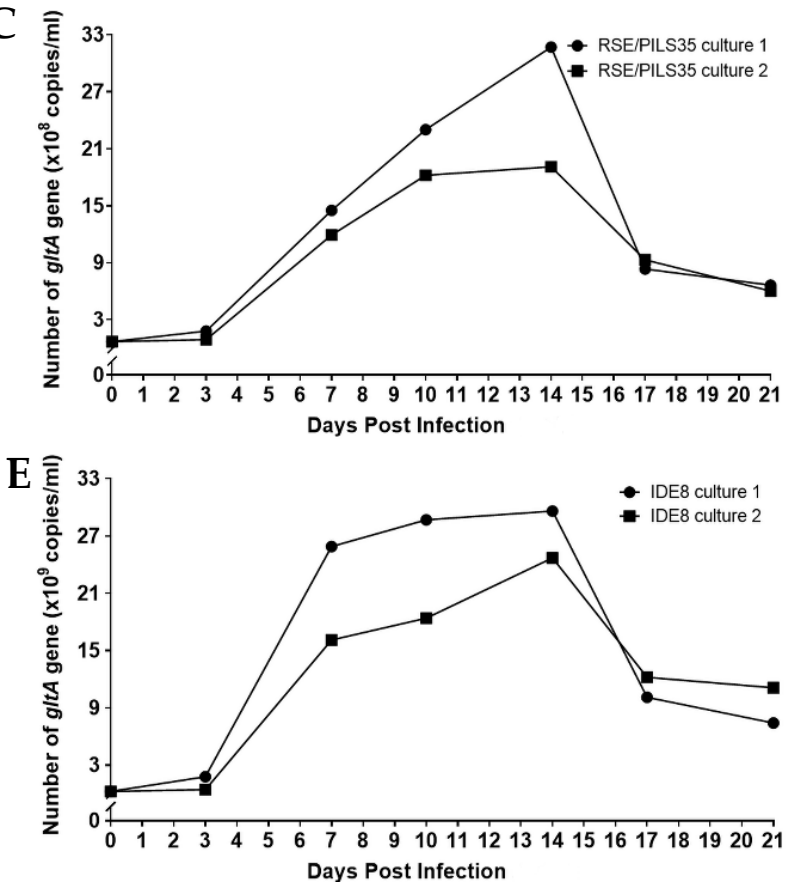

B

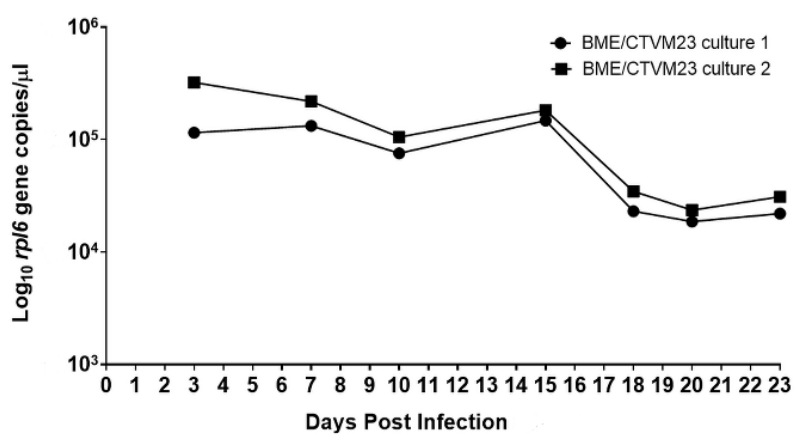

D

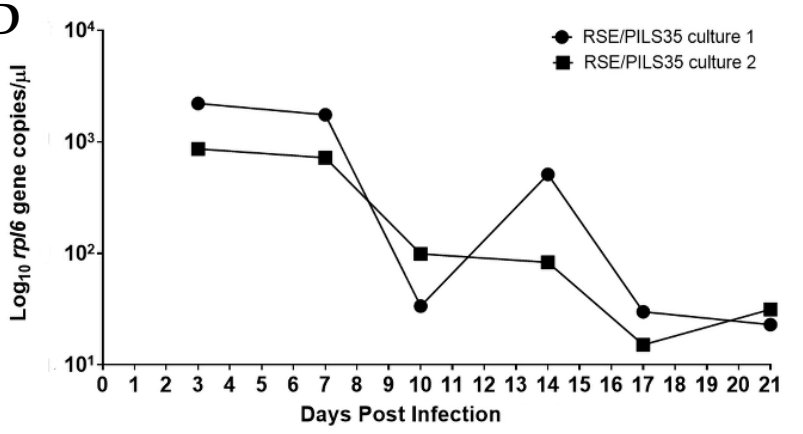

$\mathbf{F}$

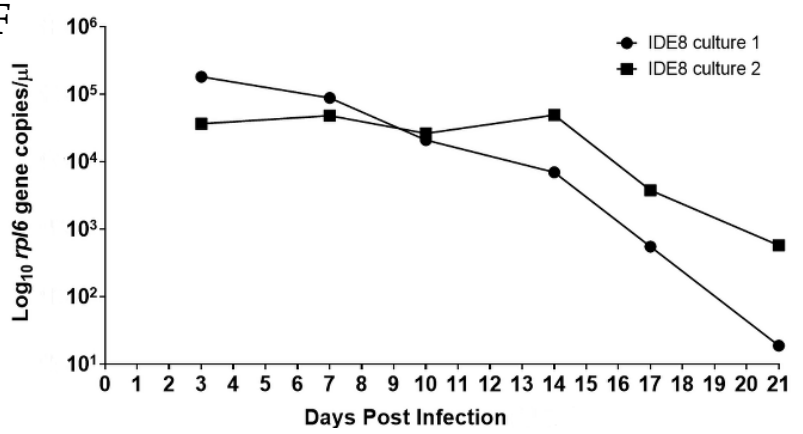

Figure 3. Replication kinetics of Rickettsia raoultii in tick cell lines. The growth curves for $R$. raoultii were established based on the copy number of rickettsiae-specific glt $A$ gene determined for two replicate cultures each of the tick cell lines BME/CTVM23 (A), RSE/PILS35 (C) and IDE8 (E). Concurrently, the tick cell copy number was determined by amplification of the tick-specific rpl6 gene for each of the BME/CTVM23 (B), RSE/PILS35 (D) and IDE8 (F) cultures.

For the IDE8 cells, approximately $2.46 \times 10^{8}$ DNA copies of $R$. raoultii were used to initiate infections in both the cultures, as indicated on $0 \mathrm{dpi}$ (Figure 3E). The growth curves for both the IDE8 cell cultures demonstrate an initial lag phase from 0 to $3 \mathrm{dpi}$. This was followed by an exponential increase from 3 to $7 \mathrm{dpi}$, a subsequent stationary phase from 7 to $14 \mathrm{dpi}$, and a declining phase from 14 to $17 \mathrm{dpi}$, which remained low until $21 \mathrm{dpi}$ in both the cultures. The mean generation time for $R$. raoultii in the IDE8 cultures was 0.9 day. On $14 \mathrm{dpi}$, the highest mean copy number was recorded at $2.71 \times 10^{10} \mathrm{copies} / \mathrm{mL}$, representing an approximately 110.1-fold increase compared to the inoculum. Simultaneously, a gradual decrease in the tick cell numbers, as represented by the rpl6 target copy number, was observed in both the $R$. raoultii-infected IDE8 cell cultures, from 3 to $14 \mathrm{dpi}$, followed by a steeper decline until $21 \mathrm{dpi}$, as the infected cells began to die (Figure 3F).

\section{Discussion}

The data presented in the present study reveal that $R$. raoultii is able to infect and propagate in the R. microplus-derived BME/CTVM23, R. sanguineus-derived RSE/PILS35, and I. scapularis-derived IDE8 cell lines. The BME/CTVM23 cell line was selected for study because the $R$. raoultii strain used was isolated in this line [21], and the RSE/PILS35 cells were used because $R$. raoultii has previously been isolated in another $R$. sanguineus cell 
line [24]. I. scapularis cell lines are known to be permissive to infection with North American Rickettsia spp. [32-36]; the IDE8 line was used to determine whether I. scapularis cells were able to support replication of the Eurasian species $R$. raoultii. The presence of noticeable cytopathic effect was observed in all the infected tick cells in this study. However, a previous study [21] has shown that $R$. raoultii caused almost no cytopathic effect in primary Dermacentor marginatus cell cultures despite, or perhaps because of, this species being one of the main arthropod vectors of the bacterium.

The infection rate curves showed that the percentage of infected cells in all three cell lines increased steadily from less than $40 \%$ at 3 dpi to $100 \%$ of the cells at the end of the observation period. Since the quantification of bacteria from Giemsa-stained cytocentrifuge smears is difficult, due to the variable number of bacteria infecting a single cell, it is necessary to perform qPCR alongside to determine the growth of bacteria in the infected cells.

Generally, the replication kinetics for bacteria can be represented by the following four common phases: the lag phase, exponential phase, stationary phase, and death phase [37]. These growth phases could be seen in both the infected IDE8 cultures and one of the infected RSE/PILS35 cultures. Similar replication kinetics of $R$. raoultii and Rickettsia rickettsii bacteria were observed in Vero cells, in which all four phases were observed [38,39]. In contrast, the stationary phase was not detected in either of the infected BME/CTVM23 cultures and one of the RSE/PILS35 cultures. For intracellular bacteria, such as $R$. raoultii, the death phase may occur when all the cells in the culture are infected and they begin to die. This could be observed in the decline of the tick cell copy numbers, and the onset of the bacterial death phase after $100 \%$ of the cells were infected in all three cell lines. The high bacterial numbers appear to have promoted rapid cell death and prevented the occurrence of a stationary phase in the BME/CTVM23 and RSE/PILS35 cultures.

An initial lag phase in the $R$. raoultii copy numbers early in the infection was observed in both the infected RSE/PILS35 and IDE8 cultures. This observation may represent the adaptation of the bacteria to the host cell during the lag phase. The presence of a lag phase after the introduction of the bacterial inoculum was consistent with other studies of replication kinetics for different Rickettsia spp. in mammalian cell lines. These include lag phases of 7 days for $R$. raoultii [38], 2 days for $R$. helvetica [40], and 1 day for $R$. rickettsii [39] during infection of Vero cells, 6 days for $R$. raoultii during infection of L929 cells [38], and $7.5 \mathrm{~h}$ for $R$. prowazekii during infection of chicken embryonic cells [41]. The variable lengths of the lag phase for the different rickettsial species may be influenced by how the bacteria adapt to the different cell lines and the culture conditions. In addition, the length of the lag phase may also be dependent on the bacterial growth phase from which they were isolated for use in the infection [42]. On the other hand, the lag phase was not detected in either of the infected BME/CTVM23 cultures. The absence of a lag phase may be because the bacteria were originally propagated in BME/CTVM23 cells, hence they were already accustomed to growth in this cell line.

The mean lengths of the exponential phase for $R$. raoultii infection in tick cells, ranging from four to twelve days, were observed to be longer than the reported lengths of the exponential phase during $R$. raoultii and $R$. slovaca infections in mammalian cells $[38,43]$. Apart from IDE8, the generation times for $R$. raoultii in the infected tick cultures ranged from 1.6 to 2.2 days, which are also greater than the generation times reported for $R$. raoultii and $R$. slovaca in mammalian cells, which ranged from 20 to $22 \mathrm{~h}[40,43]$. The discrepancy observed in the growth rate of $R$. raoultii could be due to two possible reasons. Firstly, the infected tick cell cultures were maintained at a lower temperature compared to the usual incubation temperatures for the infected mammalian cells in previous studies, which could have influenced the growth rate of the bacteria. A recent report showed that Candidatus Rickettsia vini induced cell death in tick and Vero cells at approximately the same rate at incubation temperatures of, respectively, $28{ }^{\circ} \mathrm{C}$ and $32{ }^{\circ} \mathrm{C}$ [44]. Secondly, there may be possible variation in the interaction between the rickettsiae and the different cell lines. 
The increase in $R$. raoultii numbers observed during infection also varied between the tick cell lines tested in our study. The overall increase in bacterial numbers, compared to the starting inoculum in the IDE8 cultures, appeared to be greater than in the BME/CTVM23 and RSE/PILS35 cultures (i.e., 101.1 times vs. 39.5 and 37.1 times). This observation suggests that $R$. raoultii were able to multiply to higher numbers in the IDE8 cells. Furthermore, a stationary phase lasting up to seven days could be observed in the infected IDE8 cultures, and there was only a marginal decline in the tick gene copy numbers during this phase. This suggests that IDE8 cells may be more tolerant than the other two cell lines of heavy bacterial burden before the onset of cell death in the culture conditions used.

In conclusion, we have demonstrated that $R$. raoultii can infect and propagate in BME/CTVM23, RSE/PILS35 and IDE8 cell lines, representing three species of metastriate and prostriate ticks not known to harbor this bacterium in nature. We have further demonstrated the growth kinetics of the bacteria in these cell lines. Our observations include a longer exponential phase and generation times, as well as higher bacterial multiplication levels in tick cell lines as compared to the observations in mammalian cells in previous studies. Further experiments, however, are necessary to examine the influence of incubation temperatures on bacterial growth. When the infected tick cell cultures were maintained under the same culture conditions, the IDE8 cells also appeared to be able to tolerate higher $R$. raoultii burdens and multiplication levels than the two metastriate tick cell lines. Further investigations will be necessary to determine if similar observations are made under different culture conditions, and to examine if the genotypic and phenotypic differences between the tick cell lines influence $R$. raoultii growth rates.

It is also important to note that the tick cell lines used in this study did not originate from the natural vector of $R$. raoultii and, therefore, do not represent the natural host cells of the bacteria. Nevertheless, these cell lines will still be useful for investigating arthropodpathogen interactions, especially in the absence of continuous cell lines from any of the natural arthropod vectors.

Author Contributions: Conceptualization, N.A.H., J.J.K. and L.B.-S.; methodology, N.A.H., J.J.K. and L.B.-S.; formal analysis, N.A.H. and J.J.K.; investigation, N.A.H., J.J.K., M.M.S.Z., and L.B.-S.; resources, J.J.K. and L.B.-S.; data curation, N.A.H., J.J.K. and L.B.-S.; writing-original draft preparation, N.A.H. and J.J.K.; writing—review and editing, N.A.H., J.J.K., L.B.-S. and S.A.; visualization, N.A.H., J.J.K. and L.B.-S.; supervision, J.J.K., L.B.-S. and S.A.; project administration, N.A.H. and J.J.K.; funding acquisition, J.J.K., L.B.-S. and S.A. All authors have read and agreed to the published version of the manuscript.

Funding: This research was supported by an Institutional Links grant, ID 332192305, under the Newton-Ungku Omar Fund partnership. The grant was funded by the UK Department of Business, Energy and Industrial Strategy (BEIS) and the Energy and Industrial Strategy and Malaysian Industry-Government Group for High Technology (MIGHT), and delivered by the British Council. We acknowledge the funding from the Ministry of Education, Malaysia for niche area research under the Higher Institution Centre of Excellence (HICoE) program (Project MO002-2019). This study was also supported in part by research grants from the Universiti Malaya, Malaysia, under the Research University grant (RU008-2018) and Centre of Excellence Top 100 research grant (UM.00000188/HGA.GV), and by the United Kingdom Biotechnology and Biological Sciences Research Council grants BB/P024270/1 and BB/P024378/1.

Acknowledgments: We would like to thank the Tick Cell Biobank, University of Liverpool for provision of tick cell lines used in this work. We thank Professor Ulrike Munderloh, University of Minnesota, for permission to use the IDE8 cell line.

Conflicts of Interest: The authors declare no conflict of interest. The funders had no role in the design of the study; in the collection, analyses, or interpretation of data; in the writing of the manuscript, or in the decision to publish the results. 


\section{References}

1. Rydkina, E.; Roux, V.; Rudakov, N.; Gafarova, M.; Tarasevich, I.; Raoult, D. New Rickettsiae in ticks collected in territories of the former Soviet Union. Emerg. Infect. Dis. 1999, 5, 811-814. [CrossRef] [PubMed]

2. Mediannikov, O.; Matsumoto, K.; Samoylenko, I.; Drancourt, M.; Roux, V.; Rydkina, E.; Davoust, B.; Tarasevich, I.; Brouqui, P.; Fournier, P.-E. Rickettsia raoultii sp. nov., a spotted fever group rickettsia associated with Dermacentor ticks in Europe and Russia. Int. J. Syst. Evol. Microbiol. 2008, 58, 1635-1639. [CrossRef] [PubMed]

3. Selmi, M.; Martello, E.; Bertolotti, L.; Bisanzio, D.; Tomassone, L. Rickettsia slovaca and Rickettsia raoultii in Dermacentor marginatus ticks collected on wild boars in Tuscany, Italy. J. Med. Entomol. 2009, 46, 1490-1493. [CrossRef] [PubMed]

4. Duscher, G.G.; Hodžić, A.; Weiler, M.; Vaux, A.G.C.; Rudolf, I.; Sixl, W.; Medlock, J.M.; Versteirt, V.; Hubálek, Z. First report of Rickettsia raoultii in field collected Dermacentor reticulatus ticks from Austria. Ticks Tick Borne Dis. 2016, 7, 720-722. [CrossRef] [PubMed]

5. Klitgaard, K.; Chriél, M.; Isbrand, A.; Jensen, T.K.; Bødker, R. Identification of Dermacentor reticulatus ticks carrying Rickettsia raoultii on migrating jackal, Denmark. Emerg. Infect. Dis. 2017, 23, 2072-2074. [CrossRef] [PubMed]

6. Speck, S.; Derschum, H.; Damdindorj, T.; Dashdavaa, O.; Jiang, J.; Kaysser, P.; Jigjav, B.; Nyamdorj, E.; Baatar, U.; Munkhbat, E.; et al. Rickettsia raoultii, the predominant Rickettsia found in Mongolian Dermacentor nuttalli. Ticks Tick Borne Dis. 2012, 3, $227-231$. [CrossRef] [PubMed]

7. Wen, J.; Jiao, D.; Wang, J.-H.; Yao, D.-H.; Liu, Z.-X.; Zhao, G.; Ju, W.-D.; Cheng, C.; Li, Y.-J.; Sun, Y. Rickettsia raoultii, the predominant Rickettsia found in Dermacentor silvarum ticks in China-Russia border areas. Exp. Appl. Acarol. 2014, 63, 579-585. [CrossRef] [PubMed]

8. Tian, Z.-C.; Liu, G.-Y.; Shen, H.; Xie, J.-R.; Luo, J.; Tian, M.-Y. First report on the occurrence of Rickettsia slovaca and Rickettsia raoultii in Dermacentor silvarum in China. Parasit. Vectors 2012, 5, 19. [CrossRef] [PubMed]

9. Seo, M.-G.; Kwon, O.-D.; Kwak, D. High prevalence of Rickettsia raoultii and associated pathogens in canine ticks, South Korea. Emerg. Infect. Dis. 2020, 26, 2530-2532. [CrossRef] [PubMed]

10. Guo, L.-P.; Mu, L.-M.; Xu, J.; Jiang, S.-H.; Wang, A.-D.; Chen, C.-F.; Guo, G.; Zhang, W.-J.; Wang, Y.-Z. Rickettsia raoultii in Haemaphysalis erinacei from marbled polecats, China-Kazakhstan border. Parasit. Vectors 2015, 8, 461. [CrossRef] [PubMed]

11. Chmielewski, T.; Podsiadly, E.; Karbowiak, G.; Tylewska-Wierzbanowska, S. Rickettsia spp. in ticks, Poland. Emerg. Infect. Dis. 2009, 15, 486-488. [CrossRef] [PubMed]

12. Liu, D.; Wang, Y.-Z.; Zhang, H.; Liu, Z.-Q.; Wureli, H.-Z.; Wang, S.-W.; Tu, C.-C.; Chen, C.-F. First report of Rickettsia raoultii and R. slovaca in Melophagus ovinus, the sheep ked. Parasit. Vectors 2016, 9, 600. [CrossRef] [PubMed]

13. Lim, F.S.; Khoo, J.J.; Tan, K.K.; Zainal, N.; Loong, S.K.; Khor, C.S.; AbuBakar, S. Bacterial communities in Haemaphysalis, Dermacentor and Amblyomma ticks collected from wild boar of an Orang Asli Community in Malaysia. Ticks Tick Borne Dis. 2020, 11, 101352. [CrossRef] [PubMed]

14. Nooroong, P.; Trinachartvanit, W.; Baimai, V.; Ahantarig, A. Phylogenetic studies of bacteria (Rickettsia, Coxiella, and Anaplasma) in Amblyomma and Dermacentor ticks in Thailand and their co-infection. Ticks Tick Borne Dis. 2018, 9, 963-971. [CrossRef] [PubMed]

15. Parola, P.; Rovery, C.; Rolain, J.M.; Brouqui, P.; Davoust, B.; Raoult, D. Rickettsia slovaca and R. raoultii in tick-borne Rickettsioses. Emerg. Infect. Dis. 2009, 15, 1105-1108. [CrossRef] [PubMed]

16. Jia, N.; Zheng, Y.-C.; Ma, L.; Huo, Q.-B.; Ni, X.-B.; Jiang, B.-G.; Chu, Y.-L.; Jiang, R.-R.; Jiang, J.-F.; Cao, W.-C. Human infections with Rickettsia raoultii, China. Emerg. Infect. Dis. 2014, 20, 866-868. [CrossRef] [PubMed]

17. Igolkina, Y.; Krasnova, E.; Rar, V.; Savelieva, M.; Epikhina, T.; Tikunov, A.; Khokhlova, N.; Provorova, V.; Tikunova, N. Detection of causative agents of tick-borne rickettsioses in Western Siberia, Russia: Identification of Rickettsia raoultii and Rickettsia sibirica DNA in clinical samples. Clin. Microbiol. Infect. 2018, 24, 199.e9-199.e12. [CrossRef] [PubMed]

18. Dong, Z.; Yang, Y.; Wang, Q.; Xie, S.; Zhao, S.; Tan, W.; Yuan, W.; Wang, Y. A case with neurological abnormalities caused by Rickettsia raoultii in northwestern China. BMC Infect. Dis. 2019, 19, 796. [CrossRef] [PubMed]

19. Switaj, K.; Chmielewski, T.; Borkowski, P.; Tylewska-Wierzbanowska, S.; Olszynska-Krowicka, M. Spotted fever rickettsiosis caused by Rickettsia raoultii-case report. Przegl. Epidemiol. 2012, 66, 347-350. [PubMed]

20. Alberdi, M.P.; Nijhof, A.M.; Jongejan, F.; Bell-Sakyi, L. Tick cell culture isolation and growth of Rickettsia raoultii from Dutch Dermacentor reticulatus ticks. Ticks Tick Borne Dis. 2012, 3, 349-354. [CrossRef] [PubMed]

21. Palomar, A.M.; Premchand-Branker, S.; Alberdi, P.; Belova, O.A.; Moniuszko-Malinowska, A.; Kahl, O.; Bell-Sakyi, L. Isolation of known and potentially pathogenic tick-borne microorganisms from European ixodid ticks using tick cell lines. Ticks Tick Borne Dis. 2019, 10, 628-638. [CrossRef] [PubMed]

22. Munderloh, U.G.; Blouin, E.F.; Kocan, K.M.; Ge, N.L.; Edwards, W.L.; Kurtti, T.J. Establishment of the tick (Acari: Ixodidae)-borne cattle pathogen Anaplasma marginale (Rickettsiales: Anaplasmataceae) in tick cell culture. J. Med. Entomol. 1996, 33, 656-664. [CrossRef] [PubMed]

23. Wijnveld, M.; Schötta, A.-M.; Pintér, A.; Stockinger, H.; Stanek, G. Novel Rickettsia raoultii strain isolated and propagated from Austrian Dermacentor reticulatus ticks. Parasit. Vectors 2016, 9, 1-7. [CrossRef] [PubMed]

24. Santibáñez, S.; Portillo, A.; Palomar, A.M.; Bell-Sakyi, L.; Romero, L.; Oteo, J.A. Isolation and maintenance of Rickettsia raoultii in a Rhipicephalus sanguineus tick cell line. Microb. Infect. 2015, 17, 866-869. [CrossRef] [PubMed] 
25. Koh-Tan, H.H.C.; Strachan, E.; Cooper, K.; Bell-Sakyi, L.; Jonsson, N.N. Identification of a novel $\beta$-adrenergic octopamine receptor-like gene ( $\beta$ AOR-like) and increased ATP-binding cassette B10 (ABCB10) expression in a Rhipicephalus microplus cell line derived from acaricide-resistant ticks. Parasit. Vectors 2016, 9, 425. [CrossRef] [PubMed]

26. Munderloh, U.G.; Liu, Y.; Wang, M.; Chen, C.; Kurtti, T.J. Establishment, maintenance and description of cell lines from the tick Ixodes scapularis. J. Parasitol. 1994, 80, 533-543. [CrossRef] [PubMed]

27. Munderloh, U.G.; Kurtti, T.J. Formulation of medium for tick cell culture. Exp. Appl. Acarol. 1989, 7, 219-229. [CrossRef] [PubMed]

28. Black, W.C.; Piesman, J. Phylogeny of hard- and soft-tick taxa (Acari: Ixodida) based on mitochondrial 16S rDNA sequences. Proc. Natl. Acad. Sci. USA 1994, 91, 10034-10038. [CrossRef] [PubMed]

29. Stenos, J.; Graves, S.R.; Unsworth, N.B. A highly sensitive and specific real-time PCR assay for the detection of spotted fever and typhus group rickettsiae. Am. J. Trop. Med. Hyg. 2005, 73, 1083-1085. [CrossRef]

30. Al-Khafaji, A.M.; Armstrong, S.D.; Varotto Boccazzi, I.; Gaiarsa, S.; Sinha, A.; Li, Z.; Sassera, D.; Carlow, C.K.S.; Epis, S.; Makepeace, B.L. Rickettsia buchneri, symbiont of the deer tick Ixodes scapularis, can colonise the salivary glands of its host. Ticks Tick Borne Dis. 2020, 11, 101299. [CrossRef] [PubMed]

31. Harley, P. Laboratory Exercises in Microbiology, 5th ed.; McGraw-Hill: London, UK, 2002.

32. Policastro, P.; Munderloh, U.; Fischer, E.; Hackstadt, T. Rickettsia rickettsii growth and temperature-inducible protein expression in embryonic tick cell lines. J. Med. Microbiol. 1997, 46, 839-845. [CrossRef] [PubMed]

33. Munderloh, U.G.; Hayes, S.F.; Cummings, J.; Kurtti, T.J. Microscopy of spotted fever rickettsia movement through tick cells. Microsc. Microanal. 1998, 4, 115-121. [CrossRef]

34. Kurtti, T.J.; Simser, J.A.; Baldridge, G.D.; Palmer, A.T.; Munderloh, U.G. Factors influencing in vitro infectivity and growth of Rickettsia peacockii (Rickettsiales: Rickettsiaceae), an endosymbiont of the Rocky Mountain wood tick, Dermacentor andersoni (Acari, Ixodidae). J. Invert. Path. 2005, 90, 177-186. [CrossRef] [PubMed]

35. Pornwiroon, W.; Pourciau, S.S.; Foil, L.D.; Macaluso, K.R. Rickettsia felis from cat fleas: Isolation and culture in a tick-derived cell line. Appl. Environ. Microbiol. 2006, 72, 5589. [CrossRef] [PubMed]

36. Kurtti, T.J.; Felsheim, R.F.; Burkhardt, N.Y.; Oliver, J.D.; Heu, C.C.; Munderloh, U.G. Rickettsia buchneri sp. nov., a rickettsial endosymbiont of the blacklegged tick Ixodes scapularis. Int. J. Syst. Evol. Microbiol. 2015, 65, 965. [CrossRef] [PubMed]

37. Fenollar, F.; Maurin, M.; Raoult, D. Wolbachia pipientis growth kinetics and susceptibilities to 13 antibiotics determined by immunofluorescence staining and real-time PCR. Antimicrob. Agents Chemother. 2003, 47, 1665-1671. [CrossRef] [PubMed]

38. Špitalská, E.; Štefanidesová, K.; Kocianová, E.; Boldiš, V. Rickettsia slovaca and Rickettsia raoultii in Dermacentor marginatus and Dermacentor reticulatus ticks from Slovak Republic. Exp. Appl. Acarol. 2012, 57, 189-197. [CrossRef]

39. Eremeeva, M.E.; Dasch, G.A.; Silverman, D.J. Evaluation of a PCR assay for quantitation of Rickettsia rickettsii and closely related spotted fever group rickettsiae. J. Clin. Microbiol. 2003, 41, 5466-5472. [CrossRef] [PubMed]

40. Elfving, K.; Lukinius, A.; Nilsson, K. Life cycle, growth characteristics and host cell response of Rickettsia helvetica in a Vero cell line. Exp. Appl. Acarol. 2012, 56, 179-187. [CrossRef] [PubMed]

41. Wisseman, C.; Waddell, A.; Silverman, D. In vitro studies on Rickettsia-host cell interactions: Lag phase in intracellular growth cycle as a function of stage of growth of infecting Rickettsia prowazeki, with preliminary observations on inhibition of rickettsial uptake by host cell fragments. Infect. Immun. 1976, 13, 1749-1760. [CrossRef] [PubMed]

42. Marcelino, I.; Veríssimo, C.; Sousa, M.F.; Carrondo, M.J.; Alves, P.M. Characterization of Ehrlichia ruminantium replication and release kinetics in endothelial cell cultures. Vet. Microbiol. 2005, 110, 87-96. [CrossRef] [PubMed]

43. Boldiš, V.; Špitalská, E. Dermacentor marginatus and Ixodes ricinus ticks versus L929 and Vero cell lines in Rickettsia slovaca life cycle evaluated by quantitative real time PCR. Exp. Appl. Acarol. 2010, 50, 353-359. [CrossRef] [PubMed]

44. Al-Khafaji, A.M.; Bell-Sakyi, L.; Fracasso, G.; Luu, L.; Heylen, D.; Matthysen, E.; Oteo, J.A.; Palomar, A.M. Isolation of Candidatus Rickettsia vini from Belgian Ixodes arboricola ticks and propagation in tick cell lines. Ticks Tick Borne Dis. 2020, $11,101511$. [CrossRef] [PubMed] 